\title{
Resepsi Sinkronis Alumni Mahasiswa FIB UNS terhadap Keindahan Puisi Berbahasa Indonesia dalam Lagu $A$ Rose In The Wind Karya Anggun
}

\author{
Irwanto \\ Fakultas Ilmu Budaya, Universitas Diponegoro \\ erwanferman@yahoo.co.id
}

\begin{abstract}
This research aimed on the responses from almuni of the UNS Faculty of Humanities to Indonesian poetry in Anggun C Sasmi's international song A Rose in The Wind. The agreement that used in this study is the synchronous acceptance of literary work. The researcher chosed and interviewed 5 respondents from alumni of UNS Faculty of Humanities. The result of interview resulting a data that used as material of research. The researcher found similarities and responses on the poetry tittle. There also different reason, which are some interpretation of the responded that related to feelings of regret, apologies, and nationalism. One interesting thing in this research is the shift in the meaning of natinoalism towards Indonesia. As it related to nationalism, it is not only given by the "indonesian citizen" but, it also given by "foreigner" through a love to Bahasa.
\end{abstract}

Keywords: Reader response; poetry; A Rose in The Wind; Anggun.

\section{Intisari}

Penelitian ini fokus pada respons alumni mahasiswa Fakultas Ilmu budaya UNS terhadap puisi berbahasa Indonesia dalam lagu Internasional A Rose In The Wind karya Anggun C Sasmi. Pendekatan yang digunakan dalam penelitian ini adalah resepsi sinkronis karya sastra. Peneliti memilih dan mewawancarai 5 responden alumni mahasiswa Fakultas Ilmu Budaya UNS. Data berupa hasil wawancara digunakan sebagai bahan analisis penelitian. Peneliti menemukan persamaan dan perbedaan respons pembaca pada sisi judul puisi. Adapun perbedaan respons terdapat dalam makna puisi sesuai interpretasi responden diantaranya terkait rasa peyesalan, permohonan maaf, dan nasionalisme. Satu hal yang menarik dalam penelitian ini adalah terdapat pergeseran makna nasionalisme terhadap bangsa Indonesia. Bahwa nasionalisme tidak hanya diberikan oleh "warga negara Indonesia" namun juga bisa diberikan oleh "warga negara asing" melalui kecintaan terhadap bahasa Indonesia.

Kata kunci : Respons pembaca; puisi; A Rose In The Wind; Anggun.

\section{Pendahuluan}

Kehadiran karya sastra memberikan manfaat sebagai hiburan, alat mendidik masyarakat, dan pada titik perenungan. Seniman menciptakan karya sastra dengan berbagai bentuk. Menurut Noor (2015:1) karya sastra memiliki berbagai macam bentuk mulai dari puisi, cerita pendek (cerpen), novel, roman, novella, cerita bersambung, dan lainnya.

Salah satu bentuk karya sastra yang diminati banyak kalangan adalah puisi. Menurut Waluyo (2002:1) puisi adalah karya sastra dengan bahasa yang dipadatkan, dipersingkat, dan diberi irama dengan bunyi yang padu dan diksi atau pemilihan kata kias 
Irwanto, Resepsi Sinkronis Alumni Mahasiswa FIB UNS terhadap Keindahan

(imajinatif). Puisi mengekspresikan pikiran yang membangkitkan perasaan, yang merangsang imajinasi panca indra, dalam susunan yang berirama. Sebagian seniman menulis puisi untuk dibaca monolog ada juga yang mengkombinasikan dengan melodi menjadi sebuah lirik lagu. Lirik masuk dalam kategori puisi yang sangat pendek yang mengapresiasi emosi (Semi, 1984:95). Selain itu, definisi lain menyebutkan bahwa lirik adalah karya sastra yang berisi curahan hati dan perasaan pribadi (Sudjiman, 1990:49).

Salah satu seniman Internasional asal Indonesia yang menyelipkan puisi berbahasa Indonesia dalam lagu berbahasa Inggris adalah Anggun C Sasmi. A Rose In The Wind adalah lagu ke dua dalam album Snow On The Sahara yang sangat popular hingga saat ini. Satu hal yang unik adalah ketika terdapat puisi berbahasa Indonesia di tengah lagu berdurasi empat menit dua puluh tujuh detik. Selain itu komposisi musik etnik berupa seruling turut memberikan kesan kedaerahan khas Indonesia.

Orang awam dan pembaca sastra yang menikmati puisi ini pasti memiliki beragam interpretasi. Lagu ini sering dinyanyikan oleh Anggun dalam tur internasional di berbagai negera termasuk di Italia, Filipina, Singapura, dan negara lainnya. Lagu ini dianggap unggul karena menjadi salah satu lagu terbaik versi radio editor majalah Billboard, setelah "My Heart Will Go On" milik Celine Dion (Majalah Billboard edisi 26 Des 1998 - 2 Jan 1999). Kemudian lagu ini juga terpilih sebagai salah satu lagu tema liga basket Amerika (NBA) bersama lagu internasional lainnya (www.ebay.com). Saat Anggun menyanyikan lagu ini, apalagi di negara "tetangga" tentu akan membuat orang penasaran dengan adanya puisi berbahasa Indonesia di tengah lirik berbahasa Inggris. Sesuai yang disampaikan Anggun di majalah Billboard edisi 25 April 1988 bahwa lagu ini adalah single yang paling ia sukai di album Snow On The Sahara. Bagi Anggun lagu ini secara lirik adalah perpaduan antara timur dan barat (Asia dan Eropa). Representasi perjuangannya meninggalkan Indonesia dan menjangkau ranah Internasional. Bahasa Indonesia sebagai bahasa ibunya dimanfaatkan untuk menjadi sarana perpaduan budaya sekaligus memperkenalkan bahasa Indonesia di tataran Internasional.

Puisi berbahasa Indonesia dalam lagu A Rose In The Wind juga menjadi cermin seorang seniman yang sudah diakui dunia masih menggunakan unsur budaya yakni bahasa (Indonesia) dalam berkarya. Hal yang mendasar tentang nasionalisme terletak pada budaya termasuk bahasa, sejarah, identitas yang serupa. Seseorang memiliki identitas sebagai bangsa tertentu karena kesamaan hal-hal mendasar tadi dan mau memperjuangkan. (Ryan, 
Irwanto, Resepsi Sinkronis Alumni Mahasiswa FIB UNS terhadap Keindahan

Puisi Berbahasa Indonesia

2005 : 139). Pendapat lain menyebutkan bahwa Nasionalisme adalah perjuangan kombinasi antara ras, entitas, budaya termasuk bahasa dan kesamaan sejarah. (Vioti \& Kauppi, 2007 : 464).

Bahasa Indonesia digunakan Anggun C Sasmi untuk menunjukan salah satu eksistensinya sebagai bagian dari bangsa Indonesia. Hal ini menarik untuk dikaji sebab seniman mencurahkan imajinasi dan pemikirannya melalui bait-bait puisi dengan berbagai tujuan, begitu juga dengan Anggun. Kehadiran puisi memunculkan berbagai respons dari masyarakat. Hal ini menarik untuk dikaji karena menjadi satu indikator bermanfaat atau tidaknya kehadiran karya sastra itu. Saat ini Anggun C Sasmi berkarier dan bermukim di Eropa, tepatnya sebagai Warga Negara Perancis. Ia memilih sebagai Warga Negara Perancis disebabkan ketika bekarier internasional menggunakan paspor Indonesia susah menembus negara-negara di Eropa. Namun, jika dilihat dari hasil karyanya, Ia berusaha menampakkan jati diri sebagai Indonesia. Hal ini mengamini satu pendapat lain tentang nasionalisme yakni Nasionalisme tidak hanya hal fisik dan ide. Tidak pula terpaku pada konteks sejarah, yaitu ketika sejarawan terpaku pada asal-usul bangsa. Namun harus dikaitkan juga dengan isu-isu politik dan modernitas (Bhabha, 2007 : 203). Keindahan puisi atau lirik tidak sekadar hiburan, namun dalam konteks yang lebih luas juga tentang penyampaian gagasan dan ungkapan seorang seniman dengan karyanya.

\section{Metode Penelitian}

Peneliti membahas tentang respons pembaca puisi karya Anggun C Sasmi dalam lagu $A$ Rose In The Wind. Bagaimana dan seperti apa tanggapan masyarakat tentang puisi ini. Salah satu teori sastra yang pas untuk membahas ini adalah resepsi sastra. Resepsi sastra merupakan aliran sastra yang meneliti teks sastra dengan mempertimbangkan pembaca selaku pemberi sambutan atau tanggapan. Dalam memberikan sambutan dan tanggapan tentunya dipengaruhi oleh faktor ruang, waktu, dan golongan sosial. Dalam arti luas resepsi diartikan sebagai pengolahan teks, cara-cara pemberian makna terhadap karya sehingga dapat memberikan respons terhadapnya. Respons yang dimaksudkan tidak dilakukan antara karya dengan seorang pembaca, melainkan pembaca sebagai proses sejarah, pembaca dalam periode tertentu (Ratna 2009: 165).

Resepsi sastra dalam perkembangannya dibagi menjadi dua bidang kajian. Kualitas keindahan menurut teori-teori postkolonial, khususnya resepsi memberikan kesempatan seluas-luasnya bagi pembaca untuk menilai, mengartikan, dan memaknai karya sastra. 
Secara metodologis kualitas estetika sastra seharusnya digali melalui dan didalam kearifan pembaca, dengan alasan pembacalah, yaitu masyarakat sastra pada umumnya yang memberikan penilaian terhadapnya, baik pada tataran sinkronis maupun diakronis (Ratna 2007: 277).

Peneliti melakukan penelitian ini dalam tataran resepsi sinkronis terhadap 5 orang alumni mahasiswa Fakultas Ilmu Budaya UNS. Peneliti melakukan wawancara dengan narasumber untuk mengetahui tanggapan masing-masing. Apakah ada persamaan dan perbedaan tanggapan dari masing-masing narasumber dan bagaimana deskripsi tanggapan tersebut.

Menurut Endraswara (2008:126) proses kerja penelitian resepsi sastra secara sinkronis atau penelitian secara eksperimental, minimal menempuh dua langkah sebagai berikut:

a. Setiap pembaca perorangan maupun kelompok yang telah ditentukan, disajikan sebuah karya sastra. Pembaca tersebut lalu diberi pertanyaan baik lisan maupun tertulis. Jawaban yang diperoleh dari pembaca tersebut kemudian dianalisis menurut bentuk pertanyaan yang diberikan. Jika menggunakan angket, data penelitian secara tertulis dapat ditabulasikan. Sedangkan data hasil penelitian, jika menggukan metode wawancara, dapat dianalisis secara kualitatif.

b. Setelah memberikan pertanyaan kepada pembaca, kemudian pembaca tersebut diminta untuk menginterpretasikan karya sastra yang dibacanya. Hasil interpretasi pembaca ini dianalisis menggunakan metode kualitatif.

\section{Hasil dan Pembahasan}

Peneliti menentukan narasumber sezaman sesuai dengan teori resepsi sinkronis. Lima alumni mahasiswa Fakultas Ilmu Budaya UNS dipilih karena memiliki latar belakang mahasiswa sastra (meskipun ada yang berbeda jurusan). Peneliti ingin mengetahui seberapa dalam mereka mengintepretasi puisi karya Anggun C Sasmi tersebut. Satu hal yang unik adalah puisi itu tanpa judul karena berada di tengah lirik berbahasa Inggris. Masing-masing narasumber memberikan rekomendasi judul berikut tanggapan mereka berdasarkan pengalaman hidup yang dialami masing-masing. Berikut ini adalah puisi berbahasa Indonesia dalam lagu A Rose In The Wind karya Anggun C Sasmi.

Garuda, maafkan aku yang melupakanmu.

Tetapi cinta lebih kuat dari perbatasan. 
Irwanto, Resepsi Sinkronis Alumni Mahasiswa FIB UNS terhadap Keindahan

Biarkan aku jadi kompas-mu.

Kan ku tunjuk laharmu kearah gunung berapi dimasa kecilku

Bawa aku bersama angin mu.

Berikut interpretasi narasumber terhadap puisi berbahasa Indonesia dalam lagu internaslional berjudul A Rose In The Wind karya Anggun C Sasmi.

a. Eki Putri Ma'rufi : Seorang alumni mahasiswa FIB UNS jurusan Sastra Indonesia keturunan Jawa-Sunda memberikan Judul puisi "Kau Selalu di Hati". Ia menganggap puisi itu sangat menginspirasinya. Ia menilai puisi itu adalah curahan hati Anggun yang pindah kewarganegaraan. Eki memberikan apresiasi kepada Anggun meskipun dia Warga Negara Asing tetap mencintai tanah kelahirannya. Ia menyukai puisi ciptaan Anggun dibagian "Kan ku tunjuk laharmu kearah gunung berapi dimasa kecilku". Pemilihan kata pada bagian tersebut menyuratkan rasa nasionalisme yang tinggi dari anak bangsa yang sudah mendunia.

Tanggapan Eki terhadap puisi karya Anggun tersebut berkaitan dengan kewarganegaraan Anggun yang sudah tidak Indonesia lagi. Eki memberikan gambaran bahwa Anggun masih memiliki kecintaan yang tinggi terhadap Indonesia dibuktikan melalui karyanya. Terdapat fakta yang menyatakan bahwa Anggun C Sasmi memilih kewarganegaraan Perancis karena untuk kemudahan bekerja. Ia sudah memiliki mimpi untuk keluar dari Indonesia untuk mewujudkan mimpi sebagai seniman internasional. Dalam sebuah wawancara Anggun menyampaikan bahwa saat perjuangan awal menembus pasar Internasional masih banyak negara-negara yang akan ia kunjungi belum memiliki hubungan bilateral. Sehingga menggunakan paspor Indonesia belum bisa.

"I feel that it's not the color of the passport of my passport that change who I am. I mean that doesn't change my origin, my blood, my childhood, my parents, or my language as a matter of fact it really is a tool for me at first to be able to visit those countres because you know having an Indonesian passport back then and still now is quite complicated to travel the world"

Pernyataan di atas juga menjadi penjabaran Anggun bahwa ia tetap menjadi Indonesia walaupun sudah berganti warna paspor. Ia juga menegaskan bahwa "language" (bahasa Indonesia) tetap menjadi salah satu identitasnya. Hal ini bisa disimpulkan bahwa

\footnotetext{
${ }^{1}$ Data diakses dan diunduh dari lama youtube Anggunesia pada tanggal 7 Juli 2019. Data berada di menit ke 09:35 pada video berjudul Mishal Husain Meets Anggun - BBC World News [Full Duration] dipublikasikan pada tanggal 13 Desember 2012
} 
ketia ia menulis puisi berbahasa Indonesia dalam lagu berbahasa Inggris adalah kesengajaan dan sebagai bentuk kecintaan terhadap bahasa Indoensia.

b. Hasan : Seorang mahasiswa Jurusan Bahasa dan Sastra Indonesia sekaligus mantan ketua lembaga keilmiahan mahasiswa FIB UNS. Ia lahir di Karanganyar asli etnis Jawa. Ia merekomendasikan judul "Merah Putih Memilihmu". Hasan fokus pada pemilihan kata "maaf" ini menunjukan ada hal yang Anggun sesalkan namun ada pesan yang besar yang ingin disampaikan.

c. Mujahid Zainul : Mahasiswa Jurusan Bahasa dan Sastra Indonesia ini berasal dari Purwokerto. Ia merekomendasikan puisi karya Anggun dengan judul "Ragaku Untukmu". Ia mendapatkan kesan mendalam dari puisi Anggun, terkait dengan rasa nasionalisme dan pengabdian. Adapun bagian yang paling ia sukai adalah pada bait "Biarkan aku jadi kompasmu dan akan aku tunjuk laharmu ke arah gunung berapi".

Anggun memilih diksi "kompas" dianggap memiliki maksud agar bisa memberikan keteladanan untuk generasi berikutnya yang akan berkarier di skala Internasional. Pendapat ini sekaligus mengamini apa yang ditulis di laman wikipedia dan www.webcitation.org. Web itu menyebutkan bahwa Anggun sudah menjadi teladan untuk Coco Lee (Hongkong), Utada Hikaru (Jepang), Tata Young (Thailand), dan Yuna (Malaysia) untuk go Internasional.

Yuna memberikan testimonikanya disalah satu wawancara stasiun radio di Amerika bahwa Anggun menjadi menginspirasinya untuk hijrah ke negara orang untuk Go Internasional.

"Ketika saya masih kecil di Malaysia. Salah satu kegemaran saya adalah melihat musik video. Saya ingat menonton Anggun Snow On The Sahara dan berpikir Oh My God sangat cantik, Oh My God suaranya sangat indah. Saya tahu dia benarbenar meninggalkan Indonesia untuk pergi ke Eropa untuk mengejar mimpinya. Saya mengikuti jejaknya dan sepuluh tahun kemudian kami bertemu di Roma dan dia adalah penyanyi dan orang yang sangat baik".2

\footnotetext{
${ }^{2}$ Data diakses dan diunduh dari lama youtube RidwanYoung Channel pada tanggal 20 Juni 2019. Data berada di menit ke 00:10 pada video berjudul Yuna on Anggun for Asian Pasific American Heritage Month 2017 dipublikasikan pada tanggal 1 Agustus 2017.
} 


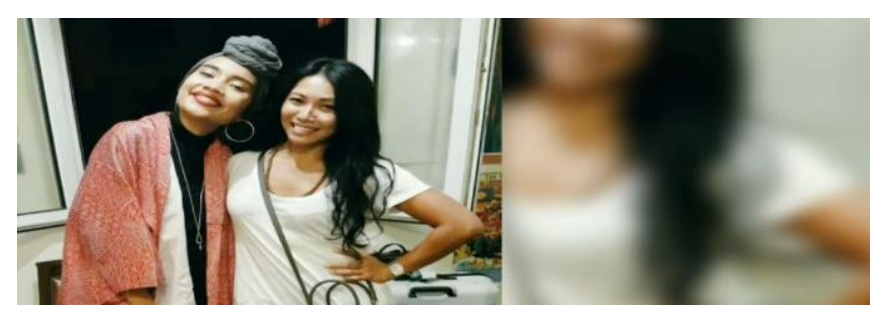

(Gb. 1. Yuna menjadikan Anggun sebagai teladan)

(Sumber : https://www.youtube.com/watch?v=7lpx-cBEMmI)

Selain Yuna, Agnez Mo salah satu seniman asal Indonesia yang merintis karier seni di Amerika juga menganggap Anggun sebagai "kompas" untuk berkarya.

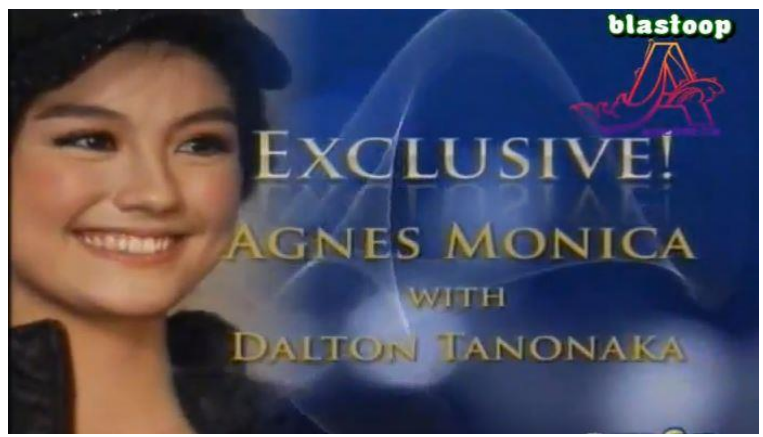

(Gb. 2 AgnezMo menjadikan Anggun sebagai panutan)

(Sumber : https://www.youtube.com/watch?v=aMYkIgF9IfU)

"Keberaninnya untuk pindah kesana jelas istimewa, dia berhasil dan panutan dalam bermusik"

d. Mustaqim : Mahasiswa Sastra Arab FIB UNS ini berasal dari Kebumen asli etnis Jawa. Ia memberikan rekomendasi puisi berjudul "Maafkan Aku". Menurutnya puisi ini memberikan kesan untuk selalu ingat tanah kelahirannya. Nasionalisme adalah tema besar dari puisi yang diangkat di dalam lagu berbahasa Inggris $A$ Rose In The Wind karya Anggun. Puisi ini juga dianggap mewakili narasumber yang sama-sama meninggalkan daerah asalnya. Satu spirit yang sama adalah siap untu berprestasi dan berkarya dan berkontribusi kepada masyarakat luas.

e. Gun Gun Gunawan : Ia adalah mahasiswa Sastra Arab UNS sekaligus Mahasiswa Berprestasi FIB UNS. Gun-gun adalah etnis Sunda yang menganggap puisi Anggun sangat mengispirasi. Ia memberikan rekomendasi puisi itu dengan judul "Garuda". Poin penting yang menjadi tanggapan dari Gun-gun adalah rasa nasionalisme.

\footnotetext{
${ }^{3}$ Data diakses dan diunduh dari lama youtube AGNEZMO Channel pada tanggal 28 Juli 2019. Data berada di menit ke 03:33 pada video berjudul Agnes Monica with Dalton Tanoka Part ldipublikasikan pada tanggal 8 Juni 2011.
} 
Lima mahasiswa yang peneliti pilih sebagai narasumber memberikan respons yang beragam (ada persamaan dan perbedaan). Perbedaan yang cukup mencolok terkait dengan pemberian judul puisi sebagai berikut, (1) Eki (Kau Selalu di Hati), (2) Hasan (Merah Putih Memilihmu), (3) Zainul (Ragaku Untukmu), (4) Mustaqim (Maafkan Aku), (5) GunGun (Garuda). Adapun persamaan respons dari kelima narasumber ialah tentang.

a. Makna nasionalisme : Melalui puisi yang ditulis Anggun di lagu A Rose In The Wind narasumber menganggap tindakan itu sebagai bentuk cinta tanah air. Pendapat narasumber sekaligus membuat konstruksi baru tentang arti cinta tanah air. Anggun berhasil membuat alternatif kepada masarakat Indonesia untuk berkontribusi kepada negara dengan cara berbeda.

b. Pergeseran makna nasionalisme : Beberapa narasumber menyebutkan bahwa Anggun menggunakan kata "maaf". Hal ini dianggap representasi ungkapan penyesalan. Menurut beberapa orang diberbagai jejaring sosial bahwa Anggun menjadi penghinat bangsa karena pindah status kewarganegaaan. Beberapa diantaranya adalah sebagai berikut komentar di laman youtube ini.

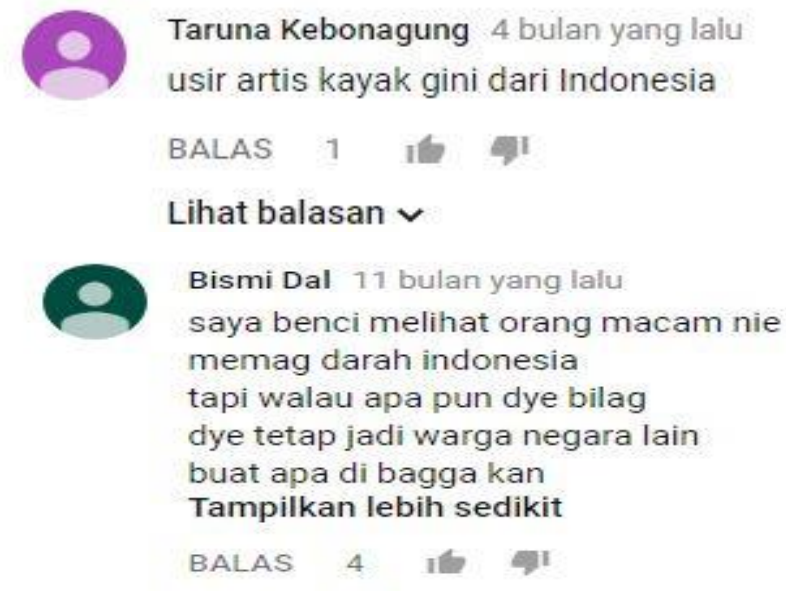

(Sumber : https://www.youtube.com/watch?v=zDLWdl2Hv6M)

Hal ini menjadi pergeseran makna nasionalisme bahwa ada "Warga Negara Asing" yang sangat cinta Indonesia. Namun banyak WNI yang tidak cinta kepada Indonesia bahkan tidak bisa berbahasa Indonesia. Hal ini juga senada dengan apa yang diungkapkan saat wawancaranya dengan salah satu TV Nasional di Indonesia tentantng kewarganegaraannya. Salah satu kutipan wawancaranya sebagai berikut. "Anakku yang besar di Perancis fasih berbahasa Indonesia, dan namanya kirana. 
Bahasa Indonesia fasih. Sisi nasionalisme itu adalah dibahasa dan seberapa besar kita berkontribusi kepada negara ${ }^{4}$."

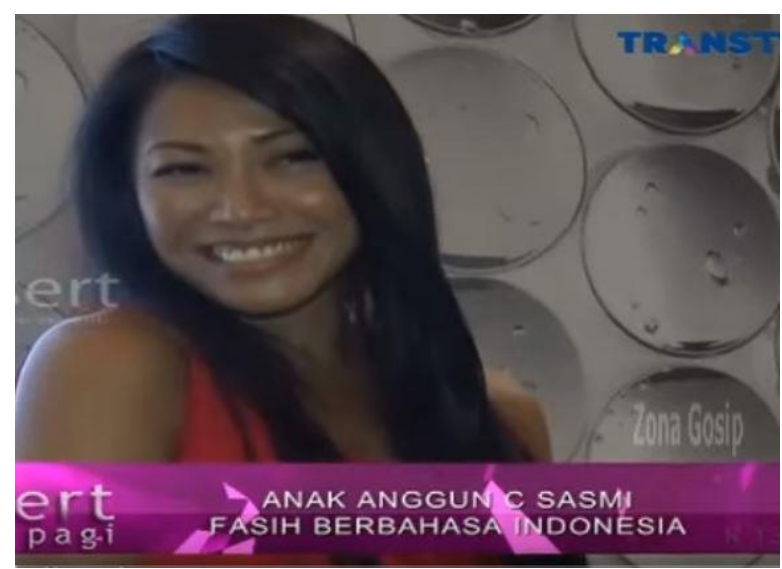

(Gb. 3. Anak Anggun pandai berbahasa Indonesia)

Kelima narasumber memberikan gambaran yang sama dengan pendapat Anggun. Ia keluar dari Indonesia tetapi memberikan contoh nasionalisme dengan cara lain. Zainul (narasumber ke 4) merasa apa yang dilakukan Anggun adalah cerminan apa yang ia lakukan sekarang. Ia berjuang keluar daerahnya untuk meweujudkan mimpinya. Meskipun keluar daerah namun masih memiliki kecintaan kepada daerahnya dan siap kembali untuk berkontribusi.

\section{Simpulan}

Puisi berbahasa Indonesia di lagu A Rose In The Wind karya Anggun C Sasmi memiliki nilai keindahan terkait dengan nasionalisme. Lima narasumber alumni mahasiswa Fakultas Ilmu Budaya UNS memberikan gambaran kepada pembaca tentang makna nasionalisme dari sudut pandang berbeda. Mereka membuktikan dan memiliki pandangan baru bahwa WNA bisa saja memiliki cinta tanah air lebih tinggi dari WNI. Adapun konteks Anggun, responden mempunyai pandangan baru tentang rasa nasionalisme yang bisa ditunjukan dengan cara lain, sekalipun harus berganti paspor untuk kemudahan kerja. Peneliti juga memberikan simpulan bahwa Indonesia saat ini membutuhkan lagu dengan lirik inspiratif untuk membangun jiwa dan perspektif bangsa yang positif.

\footnotetext{
${ }^{4}$ Data diakses dan diunduh dari lama youtube Net Entertainment News Channel pada tanggal 28 Juli 2019. Data berada di menit ke 02:31 pada video berjudul Anggun C. Sasmi Kesal Seringkali Tidak Diakui Sebagai Orang Indonesia dipublikasikan pada tanggal 19 Agustus 2016.
} 


\section{Daftar Pustaka}

Bhabha, Homi. K. 2007. The Location of Culture. Cetakan ke-5. London, New York : Routledge.

Ratna, Nyoman Kutha. 2007. Estetika Sastra dan Budaya. Yogyakarta: Pustaka Pelajar.

Ratna, Nyoman Kutha. 2009. Teori, Metode, dan Teknik Penelitian Sastra. Yogyakarta: Pustaka Pelajar.

Ryan, Stephen. 2001. "Nationalism and Entic Conflict" dalam Brian White, Richard Little and Michael Smith (ed), Issues in World Politics, Second Edition. Oxford University Press.

Semi, M. Atar. 1984. Anatomi Sastra. Jakarta :Erlangga.

Sudjiman, Panuti. 1990. Kamus Istilah Sastra. Jakarta : Universitas Indonesia.

Suwardi Endraswara. 2008. Metodologi Penelitian Sastra. Yogyakarta: Media Pressindo.

Viotti, Paul R and Mark V, Kauppi. 2007. International Relations and World Politics: Security, Economy, Identity, Uper Saddle River, NJ : Pearson Prentice Hall

Waluyo, Herman J. 2002. Apresiasi Puisi. Jakarta: Gramedia Pustaka Utama.

\section{Lampiran Transliterasi Wawancara}

Narasumber 1 .

1. Nama dan Alamat?. Eki Putri Ma'rufi Alamat: Jl. KH Sufyan Tsauri 01/01 Cibeunying, Majenang, Cilacap

2. Latar belakang pendidikan? Alumni Sastra Indonesia UNS.

3. Latar belakang budaya? (asli putra daerah mana)? Asli Cilacap, keturunan Jawa-Sunda

4. Judul yang tepat untuk puisi ini? "Kau selalu di hati"

5. Apakah puisi itu menginspirasi anda? Cukup menginspirasi.

6. Apa saja respons anda terhadap puisi tersebut? Mohon disertakan penjelasannya? Menurut saya, puisi tersebut merupakan curahan hati Anggun yang memilih berpindah kewaganegaraan. Saya memberikan respons positif terkait puisi. Dalam puisi tersebut menyiratkan bahwa Anggun masih tetap mencintai Indonesia, meski ia sudah bukan lagi seorang WNI. Hal tersebut dibuktikan pada lirik Kan ku tunjuk laharmu kearah gunung berapi dimasa kecilku. Pada lirik tersebut membuktikan bahwa ia tetap mengingat Indonesia karena di sanalah ia lahir dan dibesarkan.

Narasumber 2.

1. Nama dan Alamat? Muhamad Hasan, Tunggul Rejo, Munggur, Mojogedang, Karanganyar

2. Latar belakang pendidikan? Sastra Indonesia UNS.

3. Latar belakang budaya? (asli putra daerah mana)? Jawa.

4. Judul yang tepat untuk puisi ini? Merah Putih Memilihmu

5. Apakah puisi itu menginspirasi anda? Menginspirasi

6. Apa saja respons anda terhadap puisi tersebut? Mohon disertakan penjelasannya? Menurut saya, dalam puisi tersebut tergambar betapa hati kecil pengarang masih mencintai tanah air. Walau pengarang hidup di tempat yang berbeda, tempat kelahirannya lah yang diakuinnya. Hal ini terlihat pada bait kedua dan di perjelas kembali pada bait ke empat. Ditambah lagi dalam bait pertama terungkap kata "maaf" yang lebih memberikan betapa kecewannya pengarang terhadap apa yang telah dia lakukan. 
Narasumber 3.

1. Nama dan Alamat? Mujahid Zenul Ambiya, Jl. Kampung Walang no 46, Gang Waru 1, RT 005/RW 003, Rawa Badak Selatan, Koja, Jakarta Utara.

2. Latar belakang pendidikan? Sastra Indonesia UNS.

3. Latar belakang budaya? (asli putra daerah mana)? Bapak Purwokerto, ibu Tegal, tapi lahir dan besar di Jakarta.

4. Judul yang tepat untuk puisi ini? Ragaku Untukmu.

5. Apakah puisi itu menginspirasi anda? Iya, puisi tersebut menggambarkan tentang semangat nasionalisme dan kepemimpinan dan memberikan saya gambaran bahwa kita harus sepenuhnya berkoban serta menyerahkan jiwa dan raga untuk apa yang dipimpin dan negara. Ini dari puisi ini adalah pengabdian.

6. Apa saja respons anda terhadap puisi tersebut? Menurut saya, puisi ini bercerita tentang kepemimpinan yang berlandaskan nasionalisme. Hal ini dapat diterka dari adanya diksi garuda dan perbatasan. Untuk kepemimpinan, terdapat kalimat biarkan aku jadi kompasmu dan kan kutunjuk laharmu ke arah gunung berapi. Kata kompas dapat diartikan sebagai penunjuk.

Narasumber 4.

1. Nama dan alamat : Mustaqim Alamat : Desa Purwosari, rt 03/ rw 02, Kecamatan Puring, Kabupaten Kebumen, Jawa Tengah.

2. Latar belakang pendidikan : Sastra Indonesia UNS

3. Latar Belakang Budaya: Putra daerah asli Kebumen

4. Judul yang tepat untuk puisi ini? : "Maafkan aku"

5. Apakah puisi itu menginspirasi anda? Iya, menginspirasi, untuk mengingat kembali daerah tempat kelahiran

6. Apa saja respons anda terhadap puisi tersebut? Respons terhadap puisi tersebut: Pertama, menarik perhatian terutama dengan kata "garuda". Maknanya adalah burung garuda, namun karena memang sudah menjadi pengetahuan banyak orang, garuda secara otomatis merujuk pada bangsa Indonesia sebagai lambang negara. Kedua, menjadi bahan introspeksi, dengan kata "maaf". Kata ini seakan merujuk pada diri sendiri yang berposisi sebagai pembaca. Membaca puisi ini menunjukan permohonan maaf penulis, dii saat itu pula pembaca secara tidak langsung juga akan menyamakan dirinya dengan penulis (mengevaluasi, apakah dirinya sama kondisinya seperti puisi tersebut) Ketiga, inspirasi untuk berusaha menebus kesalahan. Setelah permohonan maaf, ada keinginan yang disampaikan oleh penulis untuk menebus kesalahannya. Hal ini disampaikan melalui barisbaris setelah baris pertama.

Narasumber 5.

1. Nama dan alamat lengkap : Gun Gun Gunawan/Pangandaran

2. Latar belakang pendidikan : Sastra Arab UNS.

3. Latar Belakang Budaya? Sunda

4. Judul yang tepat untuk puisi ini? "Garuda"

5. Apakah puisi itu menginspirasi anda? Sangat Menginspirasi

6. Apa saja respons anda terhadap puisi tersebut? Puisi ini memberikan pelajara kepada pembaca/pendengar untuk tetap menghormati tanah kelahiran dan asal usul. Sekalipun kita telah menjadi wrga negara $\mathrm{X}$, kita harus tetap menghormati dan mencintai negara di mana kita dilahirkan, negara tempat leluhurnya hidup. 